BMJ Open

Sport \&

Exercise

Medicine

\title{
Public health considerations regarding golf during the COVID-19 pandemic: a narrative review
}

\author{
Patrick Gordon Robinson (D) ,' Charlie Foster, ${ }^{2}$ Andrew Murray ${ }^{3,4}$
}

\begin{abstract}
To cite: Robinson PG, Foster C, Murray A. Public health considerations regarding golf during the COVID-19 pandemic: a narrative review. BMJ Open Sport \& Exercise Medicine 2021;7:e001089. doi:10.1136/ bmjsem-2021-001089
\end{abstract}

Accepted 31 March 2021
Check for updates

(c) Author(s) (or their employer(s)) 2021. Re-use permitted under CC BY-NC. No commercial re-use. See rights and permissions. Published by BMJ.

${ }^{1}$ Department of Trauma and Orthopaedics, Royal Infirmary of Edinburgh, Edinburgh, UK ${ }^{2}$ Centre for Exercise, Nutrition and Health Sciences, University of Bristol, Bristol, UK

${ }^{3}$ Physical Activity for Health Research Centre, University of Edinburgh, Edinburgh, UK ${ }^{4}$ Medical and Scientific Department, The R\&A, St. Andrews, UK

Correspondence to Dr Andrew Murray; docandrewmurray@gmail.com

\section{ABSTRACT}

Background Golf is a sport played worldwide by $>60$ million people from a variety of backgrounds and abilities. Golf's contribution to physical and mental health benefits are becoming increasingly recognised. Countries have adopted a range of restrictions to playing golf during the COVID-19 pandemic.

Aims The purpose of this narrative review was to (1) explore the literature related to the possible health benefits and risks of playing golf during the COVID-19 pandemic and (2) provide recommendations on golf-related activity from the relevant available literature.

Results Golf can provide health-enhancing physical activity. Regular physical activity is associated with physical/mental health, immune system and longevity benefits. Sense of belonging and life satisfaction significantly improved when golfing restrictions were relaxed after the first lockdown in the UK. Golf is an outdoor sport, where social distancing is possible, and if rules are followed, risk of COVID-19 transmission is likely to be low.

Conclusions Policy-makers and governing bodies should support the promotion of golf because participation brings wide ranging benefits for physical health and mental well-being. When effective risk reduction measures are used, the benefits of playing golf in most circumstances outweigh the risk of transmission.

\section{INTRODUCTION}

Golf is played by nearly 60 million people worldwide, $^{1}$ in 206 countries $^{2}$ with ages ranging from 4 to 104 years. ${ }^{3}$ Its global reach was also evidenced by its reinclusion into the 2016 Olympic Games. It allows those with varying levels of fitness and mobility to participate at a recreational level and it is one of the most popular games among middle-aged and older adults. ${ }^{45}$ Swinging the golf club requires the recruitment of a multitude of muscles ${ }^{6}$ and in the older population, it has been shown to improve balance, proprioception and muscle endurance. ${ }^{7-10}$ The sport has also shown favourable improvements in logical memory in the elderly. ${ }^{11}$ Golf is an inclusive sport and can be played with low financial costs when using municipal golf courses and new golf membership initiatives. ${ }^{12} 13$ In addition,

\section{Summary box}

What is already know?

- Golf is a popular sport played globally and can provide health-enhancing physical activity and health benefits.

- Varying degrees of restrictions have been applied to various sports including golf by policy-makers due to COVID-19.

\section{What are the new findings?}

- Risk of transmission while playing golf is likely low in part due to it being played outdoors and lending itself to social distancing.

- Golf has implemented changes to its rules to further mitigate risk and to allow for safe, low-risk participation. We provide guidance on this.

- Professional golf has shown that virus transmission can be low with established protocols despite international travel and multinational participation.

significant efforts have been made recently to improve its accessibility for disabled golfers. ${ }^{14}$

The WHO promotes physical activity across the life course, stating strong evidence for physical health, mental health and longevity benefits, ${ }^{15}$ while inactivity is a known risk factor for premature mortality. ${ }^{16}$ Playing golf can provide moderate intensity activity (with a reported general metabolic equivalents of $4.8),{ }^{17}$ while one 'round' of 18 holes can, on average, burn $1200 \mathrm{kcal}$ and a player can take approximately 11000-16000 steps over 4-8 miles. ${ }^{18} 19$ Energy expenditure is significantly lower for players who ride in carts; ${ }^{1720}$ however, they will still walk approximately 3 $\mathrm{km}$ per round. ${ }^{21}$ The sport helps children and adults meet the WHO recommendations for physical activity ${ }^{22}$ and the health benefits of golf have been well described in a scoping review by Murray et al. ${ }^{23}$ The authors studied 301 articles related to golf and health and concluded that practitioners and policymakers should be encouraged to support more people to play golf due to its associations with improved physical and mental well-being. ${ }^{23}$ Injury rates within golf are low 
compared with other sports and have been reported as 0.28-0.60 injuries per 1000 hours played. ${ }^{74}{ }^{25}$ However, rates are higher in elite/professional golfers. ${ }^{26}$

The COVID-19 pandemic has had a significant impact on all recreational, amateur and professional sports. With the introduction of social distancing globally, sporting activities were significantly inhibited, even if performed outdoors. There has been a reduction in physical activity during COVID-19 and government enforced lockdown periods $^{27}$ and suggestions have been made on how to best introduce people back to an active lifestyle. ${ }^{28}$ Golf is likely to be a suitable sport for patients looking to achieve health-enhancing physical activity in an outdoor environment during the COVID-19 pandemic.

The purpose of this narrative review was to (1) explore the literature related to the health benefits and risks of playing golf during the COVID-19 pandemic and (2) to provide recommendations on golf-related activity from the relevant available literature.

\section{Golf and physical and mental health}

Golf has been associated with an increase in life expectancy and physical health benefits. A Swedish study which analysed 300818 golfers and non-golfers reported a $40 \%$ lower mortality rate in the golfers, correlating to a 5-year increase in life expectancy regardless of gender, age or socioeconomic status. ${ }^{29}$ Methods deployed for this study demonstrate correlation, but not causation. Golfing is associated with reduction in known risk factors for cardiovascular disease including blood lipid and insulinglucose levels ${ }^{7}$ as well as body composition. ${ }^{160-32}$

\section{Immune function}

Regular physical activity benefits immune function which is important in the context of COVID-19. Klentrou et $a l^{33}$ studied the IgA concentration of the upper airways as the primary outcome following regular moderate physical activity and showed those undergoing exercise had significantly increased rates. ${ }^{33}$ Furthermore, it has been shown that regular exercise of moderate intensity is associated with a reduction in respiratory infections. ${ }^{34}$ Although there is limited evidence that physical activity directly reduces the rates of morbidity and mortality associated with COVID-19, this has been true for other viral illnesses ${ }^{35}$ and may be applicable to COVID-19.

\section{Benefits of golf during COVID-19 and for rehabilitation from illness}

It is known that COVID-19 has both direct and indirect effects on mental health. ${ }^{36}$ Sorbie $e t a l^{37}$ studied the impact of golf course closure and opening during the pandemic on well-being and life satisfaction. The authors reported that belonging, enjoyment and well-being were significantly associated with outdoor course activity and a sense of belonging and satisfaction increased following golf course reopening. ${ }^{37}$ Previous studies have shown improvements in stress and anxiety by playing golf ${ }^{38}$ and it is feasible that the green space and physical activity facilitated by golf could benefit health and well-being for some people.

Some physical activities during the COVID-19 pandemic likely have higher risk of transmission than golf, where these activities are indoors or where social distancing is not possible. Some may find golf a suitable substitute during times where COVID-19 prevalence is high and/or restrictions preclude these other activities. This may be particularly important for groups considered at higher risk, for example older adults. Golf has been shown to be associated with improved balance, ${ }^{8}$ muscular function ${ }^{39}$ and strength in older adults. ${ }^{10}$ Furthermore, it has been reported to be a suitable exercise for patients with cardiac ${ }^{40}$ and cerebrovascular disease. ${ }^{41}$

The authors of this review advise a phased return to golf with fewer holes and suitable warm-up activities prior to playing. It has been shown that a sudden increase in training load will predispose to injury ${ }^{42}$ and a graded return to sport should be advised. ${ }^{43}$

\section{Evidence of COVID-19 transmission associated with golf}

Since the COVID-19 pandemic was declared in March 2020, many countries restricted many activities, including sport, while work was done to better understand and cut transmission of the disease. ${ }^{44-46}$

Factors affecting risk of transmission include local prevalence of COVID-19, vaccination status of participants and the local population and the knowledge and behaviours of individuals and populations. Methods of transmission of COVID-19 are mainly human-to-human spread via droplets, aerosol, fomites or direct contact. ${ }^{47}$ It has since been recognised that outdoor environments have lower transmission risk than indoor ${ }^{48}$ and non-pharmaceutical interventions including social distancing/hand hygiene are effective in lowering transmission. ${ }^{46}$

Jones $e t a t^{49}$ were the first to analyse the COVID-19 transmission during elite sport. The authors concluded that the risk of transmission during rugby matches is very low but that efforts should be made to further mitigate disease transmission within the environment. ${ }^{49} \mathrm{~A}$ prospective study was performed in professional football over 9 weeks while implementing a tailored infection control programme. The authors concluded that the infection risk was highest with unprotected exposure in closed spaces and was lowest outdoors, even without social distancing. ${ }^{50}$

Golf is an equipment-based sports and there may be concerns regarding the risk of transmission via fomites on equipment. However, Edwards $e t a l^{51}$ showed that only $0.74 \%$ of COVID-19 virus was recoverable at $1 \mathrm{~min}$ in high inoculum when applied to a variety of sporting equipment (including a golf ball). Unpublished data from 32 professional golf events on the European Tour, Ladies European Tour and Challenge Tour which regularly tested participants found no transmission from golfer to golfer in outdoor environments. Although community golfers and golf clubs may not have the resources available to organisations such as the European Tour, much 


\section{Box 1 Key facets to mitigate risks when playing golf}

\section{Risk reduction in golf}

- Education regarding key measures to decrease risk.

- Attendance of those with COVID-19 symptoms/contact with persons with COVID-19 not permitted.

- Social distancing in line with national regulations.

- Effective hand hygiene.

- Minimise social contacts.

- Avoiding sharing food and beverage or shared surfaces (scorecards, rakes, pins, etc).

- Phased reintroduction of facilities and in particular indoor facilities when government regulations permit.

of the success of suppressing COVID-19 transmission is likely associated with the strict compliance with simple measures which have previously been shown to be effective such as social distancing, wearing masks, reducing time indoors and good hand hygiene. ${ }^{52}$

As an outdoor sport, where physical distancing is possible, risk of transmission may be low, if appropriate measures are followed. However, there is currently no published evidence regarding the rate of COVID-19 transmission when playing golf.

\section{Mitigating risks in golf}

Enhanced hygiene and social distancing measures have been shown to reduce incidence of COVID-19. Social distancing decreases the risk of transmission by reducing the incidence of close contact, while improved hygiene reduces disease transmission, if a contact does indeed occur. ${ }^{53}$ A number of countries have constructed guidance for returning to both recreational and professional sport during the pandemic. ${ }^{4354}$ These include golfspecific examples from The R\&A and the United States Golf Association (who together govern golf globally) ${ }^{5556}$ and the key facets are summarised in box 1 .

Professional golf events have incorporated these measures and operated in protected 'bubbles', with no player-to-player transmission seen on the European Tour, Ladies European Tour or Challenge Tour in 2020, despite weekly testing of all on site. ${ }^{57}$

The R\&A has made provisions within the rules of golf to mitigate the risk of transmission. These include the encouragement of non-competition play and if competition play does occur, there is no handling or exchanging of scorecards. Rakes have been removed from bunkers and players are subsequently allowed to use a preferred lie in light of this. The flagstick is not to be touched or removed and the hole is to be shallow to ease the retrieval of the ball from within it, minimising contact around the rim. ${ }^{55}$

Community golf should continue to implement measures to mitigate risks enabling golfers to gain 'green exercise' while encouraging hand hygiene and social distancing. Time spent at golf facilities should be kept to a minimum before and after the act of playing golf and group playing numbers should be minimised where possible. Carmody et $a \tilde{l}^{58}$ have designed risk assessments and factors to consider for COVID-19 transmission. The authors describe measures which can be implemented to decrease transmission risk in sport and suggest these could be applied to local competition golf ${ }^{58}$ and are supported by the UK All-Parliamentary Group for Golf, The R\&A and the United States Golf Association. ${ }^{55} 5960$ In addition, the Australian Institute of Sport has developed guidelines applicable to all levels of golf for the reintroduction of play. They advise a three-stage approach of increasing participant numbers and level of competition which is mirrored at both the community and elite level and emphasises a minimum of $1.5 \mathrm{~m}$ social distancing throughout. $^{43}$

\section{CONCLUSION}

Golf can provide health-enhancing physical activity to persons of all ages and is associated with physical and mental health benefits. Policy-makers are encouraged to assess the benefits as well as the risks and work with the golf industry to permit golf when suitable control measures are in place. Players should maintain social distancing, use effective hygiene measures and respect all COVID-19 protocols put in place by golf facilities, the golf industry and local and national governments.

\section{Twitter Andrew Murray @docandrewmurray}

Contributors PGR: Data collection, data analysis and manuscript writing. CF: Manuscript writing. AM: Manuscript idea, data analysis and manuscript writing.

Funding The authors have not declared a specific grant for this research from any funding agency in the public, commercial or not-for-profit sectors.

Competing interests AM has paid roles with The R\&A, European Tour and Ladies European Tour and is an associate editor at the British Journal of Sports Medicine.

\section{Patient consent for publication Not required.}

Provenance and peer review Not commissioned; externally peer reviewed.

Open access This is an open access article distributed in accordance with the Creative Commons Attribution Non Commercial (CC BY-NC 4.0) license, which permits others to distribute, remix, adapt, build upon this work non-commercially, and license their derivative works on different terms, provided the original work is properly cited, appropriate credit is given, any changes made indicated, and the use is non-commercial. See: http://creativecommons.org/licenses/by-nc/4.0/.

\section{ORCID iD}

Patrick Gordon Robinson http://orcid.org/0000-0002-8117-2968

\section{REFERENCES}

1 Farrally MR, Cochran AJ, Crews DJ, et al. Golf science research at the beginning of the twenty-first century. $J$ Sports Sci 2003;21:753-65.

2 The Royal and Ancient. Golf around the world. The Royal and Ancient, 2019.

3 Golf \& Health Scientific Meeting. The International Congress for golf and health. London, 2018.

4 National Centre for Social Research. Health survey for England. Health and Social Care Information Centre, 2012.

5 The Scottish Government. The Scottish health survey. The Scottish Government, 2013.

6 Papaliodis DN, Photopoulos CD, Mehran N, et al. Return to Golfing activity after joint arthroplasty. Am J Sports Med 2017;45:243-9.

7 Parkkari J, Natri A, Kannus P, et al. A controlled trial of the health benefits of regular walking on a golf course. Am J Med 2000;109:102-8.

8 Tsang WWN, Hui-Chan CWY. Static and dynamic balance control in older golfers. J Aging Phys Act 2010;18:1-13. 
9 Gao KL, Hui-Chan CWY, Tsang WWN. Golfers have better balance control and confidence than healthy controls. Eur J Appl Physiol 2011;111:2805-12.

10 Sell TC, Tsai Y-S, Smoliga JM, et al. Strength, flexibility, and balance characteristics of highly proficient golfers. J Strength Cond Res 2007;21:1166-71.

11 Shimada $\mathrm{H}$, Lee S, Akishita M, et al. Effects of golf training on cognition in older adults: a randomised controlled trial. J Epidemiol Community Health 2018:72:944-50.

12 Dunsmuir A. Somerset golf Club launches membership for $£ 1$ initiative: the golf business, 2020. Available: https://www. thegolfbusiness.co.uk/2020/02/somerset-golf-club-launchesmembership-for-1-initiative/

13 Rotherick S. Is golf an expensive hobby?: The Golf Business, 2020. Available: https://www.thegolfbusiness.co.uk/2020/05/is-golf-anexpensive-hobby/

14 R\&A. Disability golf, 2020. Available: https://www.randa.org/ TheRandA/Initiatives/DisabilityGolf

15 WHO. Global action plan on physical activity 2018-2030: more active people for a healthier world, 2018.

16 Lee I-M, Shiroma EJ, Lobelo F, et al. Effect of physical inactivity on major non-communicable diseases worldwide: an analysis of burden of disease and life expectancy. Lancet 2012;380:219-29.

17 Luscombe J, Murray AD, Jenkins E, et al. A rapid review to identify physical activity accrued while playing golf. BMJ Open 2017;7:e018993.

18 Kobriger SL, Smith J, Hollman JH, et al. The contribution of golf to daily physical activity recommendations: how many steps does it take to complete a round of golf? Mayo Clin Proc 2006;81:1041-3.

19 Tangen J, Sunde A, Sageie J. In accordance with governmental recommendations - a study of golf and health. J Sports Sci 2013:1:15-25

20 Zunzer SC, von Duvillard SP, Tschakert G, et al. Energy expenditure and sex differences of golf playing. $J$ Sports Sci 2013;31:1045-53.

21 Crowell B. Energy cost of participation in golf as determined by telemetry. Oklahoma State University, 1970.

22 World Health Organisation. WHO guidelines on physical activity and sedentary behaviour, 2020. Available: https://www.who.int/ publications/i/item/9789240015128

23 Murray AD, Daines L, Archibald D, et al. The relationships between golf and health: a scoping review. Br J Sports Med 2017;51:12-19.

$24 \mathrm{McHardy} \mathrm{A}$, Pollard H, Luo K. One-year follow-up study on golf injuries in Australian amateur golfers. Am J Sports Med 2007;35:1354-60.

25 Parkkari J, Kannus P, Natri A, et al. Active living and injury risk. Int J Sports Med 2004;25:209-16.

26 Gosheger G, Liem D, Ludwig K, et al. Injuries and overuse syndromes in golf. Am J Sports Med 2003;31:438-43.

27 Rogers NT, Waterlow NR, Brindle H, et al. Behavioral change towards reduced intensity physical activity is disproportionately prevalent among adults with serious health issues or Self-Perception of high risk during the UK COVID-19 Lockdown. Front Public Health 2020;8:575091.

28 Barker-Davies RM, O'Sullivan O, Senaratne KPP, et al. The Stanford Hall consensus statement for post-COVID-19 rehabilitation. $\mathrm{Br} J$ Sports Med 2020;54:949-59.

29 Farahmand B, Broman G, de Faire U, et al. Golf: a game of life and death--reduced mortality in Swedish golf players. Scand J Med Sci Sports 2009;19:419-24

30 Getchell LH. Energy cost of playing golf. Arch Phys Med Rehabil 1968;49:31-5.

31 Lemaitre RN, Siscovick DS, Raghunathan TE, et al. Leisure-time physical activity and the risk of primary cardiac arrest. Arch Intern Med 1999;159:686-90.

32 Golf \& Health. Dementia, 2021. Available: https://www.golfandhealth. org/mental-health/dementia/

33 Klentrou P, Cieslak T, MacNeil M, et al. Effect of moderate exercise on salivary immunoglobulin $A$ and infection risk in humans. Eur $J$ Appl Physiol 2002;87:153-8.

34 Gleeson M, Bishop NC, Stensel DJ, et al. The anti-inflammatory effects of exercise: mechanisms and implications for the prevention and treatment of disease. Nat Rev Immunol 2011:11:607-15.

35 Zhao M, Veeranki SP, Magnussen CG, et al. Recommended physical activity and all cause and cause specific mortality in US adults: prospective cohort study. BMJ:m2031.
36 Vindegaard N, Benros ME. COVID-19 pandemic and mental health consequences: systematic review of the current evidence. Brain Behav Immun 2020;89:531-42.

37 Sorbie GG, Beaumont AJ, Williams AK, et al. The impact of the closure and reopening of golf courses in the United Kingdom on wellbeing during the COVID-19 pandemic: a Multi-Study approach. Front Sports Act Living 2021:3:622171.

38 Belanger LJ, Plotnikoff RC, Clark AM, et al. Prevalence, correlates, and psychosocial outcomes of sport participation in young adult cancer survivors. Psychol Sport Exerc 2013;14:298-304.

39 Martinez Bustelo S, Simon B, Warner M, et al. Between-side symmetry of quadriceps thickness using ultrasound imaging in female golfers and non-golfers aged over 80 years. Osteoarthritis Cartilage 2016;24:S65.

40 Dobrosielski DA, Brubaker PH, Berry MJ, et al. The metabolic demand of golf in patients with heart disease and in healthy adults. $J$ Cardiopulm Rehabil 2002;22:96-104.

41 Schachten T, Jansen P. The effects of golf training in patients with stroke: a pilot study. Int Psychogeriatr 2015;27:865-73.

42 Schwellnus M, Soligard T, Alonso J-M, et al. How much is too much? (Part 2) International Olympic Committee consensus statement on load in sport and risk of illness. Br J Sports Med 2016;50:1043-52.

43 Hughes D, Saw R, Perera NKP, et al. The Australian Institute of sport framework for rebooting sport in a COVID-19 environment. J Sci Med Sport 2020;23:639-63.

44 National Health Service. Coronavirus (COVID-19), 2020. Available: https://www.nhs.uk/conditions/coronavirus-covid-19/

45 Centers for Disease Control and Prevention. COVID-19 2020. Available: https://www.cdc.gov/coronavirus/2019-ncov/index.html

46 European Centre for Disease Prevention and Control. National information resources on COVID-19, 2020. Available: https://www. ecdc.europa.eu/en/COVID-19/national-sources

47 World Health Organisation. Coronavirus disease 2019 (COVID-19) situation report-114, 2020

48 Bulfone TC, Malekinejad M, Rutherford GW, et al. Outdoor transmission of SARS-CoV-2 and other respiratory viruses: a systematic review. J Infect Dis 2021;223:550-61.

49 Jones B, Phillips G, Kemp S, et al. SARS-CoV-2 transmission during rugby League matches: do players become infected after participating with SARS-CoV-2 positive players? Br J Sports Med 2021. doi:10.1136/bjsports-2020-103714. [Epub ahead of print: 11 Feb 2021].

50 Schumacher YO, Tabben M, Hassoun K, et al. Resuming professional football (soccer) during the COVID-19 pandemic in a country with high infection rates: a prospective cohort study. $\mathrm{Br} J$ Sports Med 2021. doi:10.1136/bjsports-2020-103724. [Epub ahead of print: 15 Feb 2021].

51 Edwards T, Kay GA, Aljayyoussi G. SARS-CoV-2 transmission risk from sports equipment (strike). medRxiv.

52 Jones NR, Qureshi ZU, Temple RJ, et al. Two metres or one: what is the evidence for physical distancing in covid-19? BMJ 2020;370:m3223

53 Dalton CB, Corbett SJ, Katelaris AL. COVID-19: implementing sustainable low cost physical distancing and enhanced hygiene. Med J Aust 2020;212:443-6.

54 Kemp S, Cowie CM, Gillett M, et al. Sports medicine leaders working with government and public health to plan a 'return-to-sport' during the COVID-19 pandemic: the UK's collaborative five-stage model for elite sport. Br J Sports Med 2021;55:4-5.

55 R\&A. Golf during Covid-19 2021. Available: https://www.randa.org/ en/theranda/initiatives/golf-during-covid-19

56 Wallace J. Playing by the rules during the COVID-19 pandemic, 2020. Available: https://www.usga.org/content/usga/home-page/ rules-hub/rulesarticles/playing-by-the-rules-during-the-covid-19pandemic-.html

57 Robinson P, Murray A, Kinane D. Assessing the risk of SARS-CoV-2 transmission in international professional golf, 2021.

58 Carmody S, Murray A, Borodina M, et al. When can professional sport recommence safely during the COVID-19 pandemic? Risk assessment and factors to consider. Br J Sports Med 2020:54:946-8.

59 USGA. United States golf association COVID-19 resource center, 2021. Available: https://www.usga.org/course-care/covid-19resource-center.html [Accessed Mar 2021].

60 All Parlimentary Group for Golf. COVID-19 secure golf in the United Kingdom 2021: house of commons, 2021. 